\title{
Contentious Dynamics Within the Social Turbulence of Environmental (In)justice Surrounding Wind Energy Farms in Oaxaca, Mexico
}

Ramirez, Jacobo

Document Version

Accepted author manuscript

Published in:

Journal of Business Ethics

DOI:

10.1007/s10551-019-04297-3

Publication date:

2021

License

Unspecified

Citation for published version (APA):

Ramirez, J. (2021). Contentious Dynamics Within the Social Turbulence of Environmental (In)justice

Surrounding Wind Energy Farms in Oaxaca, Mexico. Journal of Business Ethics, 169(3), 387-404.

https://doi.org/10.1007/s10551-019-04297-3

Link to publication in CBS Research Portal

\section{General rights}

Copyright and moral rights for the publications made accessible in the public portal are retained by the authors and/or other copyright owners and it is a condition of accessing publications that users recognise and abide by the legal requirements associated with these rights.

\section{Take down policy}

If you believe that this document breaches copyright please contact us (research.lib@cbs.dk) providing details, and we will remove access to the work immediately and investigate your claim.

Download date: 26. Apr. 2023 


\section{Contentious Dynamics Within the Social Turbulence of Environmental (In)justice Surrounding Wind Energy Farms in Оакаса, Мехісо Jacobo Ramirez}

Journal article (Accepted version*)

Please cite this article as:

Ramirez, J. (2019). Contentious Dynamics Within the Social Turbulence of Environmental (In)justice Surrounding Wind Energy Farms in Oaxaca, Mexico. Journal of Business Ethics. https://doi.org/10.1007/s10551-019-04297-3

This is a post-peer-review, pre-copyedit version of an article published in Journal of Business Ethics. The final authenticated version is available online at:

DOI: https://doi.org/10.1007/s10551-019-04297-3

* This version of the article has been accepted for publication and undergone full peer review but has not been through the copyediting, typesetting, pagination and proofreading process, which may lead to differences between this version and the publisher's final version AKA Version of Record. 


\title{
Contentious dynamics within the social turbulence of environmental (in)justice surrounding wind farms in Oaxaca, Mexico
}

\begin{abstract}
Businesses and governments in postcolonial countries frame investments in wind energy as efforts to address climate change and sustainable development. However, when wind energy projects encroach on indigenous peoples' lives and land, there is often a lack of recognition and participation of these peoples and an unequal distribution of cost and benefits of such projects toward them, which leads to opposition against wind energy projects and often triggers conflicts for justice. Worryingly, such conditions have repeatedly resulted in the assassination of human rights defenders, which further inflames the conflict. Herein, I discuss these concepts based on a longitudinal study centered on a wind energy project in Oaxaca, Mexico, with the aim of exploring and understanding the conditions under which wind energy investments fail to respect current laws and norms, as well as the consequences of such negligence. My in-depth analysis of the actions of the government, businesses, and indigenous peoples revealed a phenomenon that is less discussed in environmental (in)justice research: the gradual and continuous transformation of indigenous peoples' norms and behaviors away from their traditional economic and cultural livelihoods. This phenomenon helps to extend the conceptual understanding of environmental (in)justice with regard to social turbulence, which is defined as the unpredictable behavior of political and social systems in contexts in which existing laws, regulations, and norms regarding environmental justice are not observed. The concept of social turbulence of environmental (in)justice helps to explain how indigenous peoples sacrifice their territories, norms, and traditions to a technical solution to climate change and sustainable development.
\end{abstract}


Keywords: environmental (in)justice, indigenous peoples, wind energy, Mexico 


\section{Introduction}

In postcolonial countries, businesses and governments are currently investing heavily in wind energy, and these investments are framed as an effort toward sustainable energy and regional development (Gobierno Federal 2012; Secretaría de Energía 2018; United Nations 2015). In the 1990s, Mexico initiated the transformation of its fossil fuel-based energy system (e.g., ZárateToledo et al. 2019) based on constitutional reforms to open the Mexican energy sector to foreign direct investment (FDI) in renewable energy (Inter-American Development Bank (IADB) 2011a, 2018). Although the Constitution of Mexico upholds the human rights enshrined in international treaties and recognizes social and economic rights (Cámara de Diputados and Congreso de la Unión 2011), the government still fails to protect civil society, and justice and peace are often absent because of the lack of rule of law (Gonzalez and Pérez-Floriano 2015). In such contexts, governments and businesses often fail to observe or enforce laws meant to protect indigenous communities, which has led to a long tradition of social unrest in the affected communities (Dunlap 2018a).

Mexico is the most dangerous country in the world for human rights defenders (Human Rights Council 2018, p. 18). In the first five months of 2017, 730 human rights violations were reportedly committed against such workers, including instances of harassment, assault, robbery, and cybercrime. More worryingly, the indigenous Zapotecas and Ikoots peoples from the Isthmus of Tehuantepec region, a region in the state of Oaxaca, southern Mexico, have reported the assassination of their people while trying to protect their territories and stop the further construction of wind farms (Dunlap 2017a). Scholars argue that businesses are trapped in ethical dilemmas because the payments and nonmonetary resources they provide to local communities to support wind energy investments (Inter-American Development Bank (IADB) 2018; Quintana 
2015) tend to divide the communities and create social unrest (Avila 2018; Del Bene et al. 2018). In such contexts, indigenous peoples suffer human rights abuses but continue to show resilience regarding their culture and traditions (Terwindt and Schliamann 2017).

The response to perceived and experienced (in)justices regarding the unfair treatment of indigenous peoples in the construction of wind farms has been studied under the concept of environmental justice (EJ) (Zárate-Toledo et al. 2019). Scholars use the tenets of EJ, i.e., distributive justice, justice of recognition, and procedural justice (Schlosberg 2013; Urkidi and Walter 2011), to study the impacts of environmental investment and misunderstandings between businesses and indigenous communities. It is argued that governments, businesses, and indigenous peoples hold competing beliefs about wind energy investment in relation to EJ's tenets, such as involvement in decision-making, access to renewable energy, and the sacrifice of indigenous lands, considering local, national, and world challenges such as climate change (Avila-Calero 2017; Avila 2018; Dunlap 2017a; Zárate-Toledo et al. 2019).

The objective of this research was to explore and understand the conditions in which wind energy investments fail to respect current laws and norms as well as the consequences of such negligence. The specific research question was as follows: "What are the consequences of wind energy investments in the Isthmus of Tehuantepec?” To achieve this objective and answer the research question, I developed a qualitative longitudinal study (2013-2019) situated in the Isthmus of Tehuantepec region, which has the most wind resources in Latin America according to the Wind Resource Map of Oaxaca (Elliott et al. 2004) and is home to over 1,500 wind turbines (Noticias del Istmo 2019; Secretaría de Energía 2018). This longitudinal research helped me to study how indigenous peoples and communities perceive justice, such as the respect of basic human rights principles, access to the benefits of wind energy investment, and rule of law. 
Building on environmental (in)justice literature (Graff et al. 2019; Maher 2018; Walker and Bulkeley 2006; Zárate-Toledo et al. 2019), this research discusses a rarely debated consequence of renewable energy investment: the gradual and continuous transformation of indigenous peoples' norms and behaviors away from their traditional economic and cultural livelihoods. The dysfunctional dynamic that exists in governments and businesses in Mexico (Gonzalez and Pérez-Floriano 2015) and other transitioning institutional contexts is also discussed based on the conceptual understanding of the social turbulence of environmental (in)justice, which is defined as the unpredictable behavior of political and social systems when existing laws and regulations are not executed with regard to EJ's tenets. In this turmoil, indigenous people who oppose wind farms seek local and international legal assistance to reverse the (in)justices against them and their territories, norms, and customs. The social turbulence concept provides a novel path for advancing our understanding of environmental (in)justice in postcolonial countries by considering indigenous peoples' visions of the environment and their norms and traditions (Avila 2018; Calvano 2008) and showing how this relates to ethical business development around the world. In addition, this concept helps to explain the sacrifices made by indigenous peoples in the name of sustainable energy and regional development.

The following section presents the theoretical context upon which the developed methodology is based. The findings section integrates past research with empirical material. The implications of the study are then further discussed in relation to studies on sustainable wind energy and indigenous communities. The paper concludes by outlining the boundary conditions and generalizability of the findings. 


\section{Theoretical context}

\section{Environmental (in)justice}

Businesses and governments frame wind energy investments as sustainable and regional development (Gobierno Federal 2012; Secretaría de Energía 2018; United Nations 2015; Vestas 2019). For them, wind farms function as a technical solution for regional development, and promote green businesses and economic growth (Avila 2018). Indigenous peoples endorse the above arguments based on an understanding that urgent action is needed to protect Mother Earth and reverse the impacts of climate change on their livelihoods (Altamirano-Jiménez 2017; Escobar 1996; PODER 2015). According to the United Nations (2018), Mother Earth "is a common expression for the planet earth in a number of countries and regions, which reflects the interdependence that exists among human beings, other living species and the planet we all inhabit." Nevertheless, many indigenous people challenge and resist the construction of wind farms that fail to implement distributive, recognition, and procedural justice (the tenets of EJ) (Dunlap 2017a, 2018c; Schlosberg 2013; Urkidi and Walter 2011). The competing visions of governments, businesses, and indigenous peoples with respect to wind energy investments are presented below in relation to EJ's tenets.

Competing visions of environmental justice (EJ)

Distributive justice is the fair and equitable distribution of costs and benefits at individual and societal levels (Lecuyer et al. 2018). The costs are not limited to the locations of wind farms. However, cost also includes access to the energy produced for the local communities. In postcolonial countries, governments and businesses present the construction of wind farms as 
regional development: a solution for the lack of basic infrastructure (e.g., water, electricity, roads, and schools), jobs, and unproductive local farming (Inter-American Development Bank (IADB) 2018; Secretaría de Energía 2018). However, under this vision, businesses have constructed wind farms for electricity self-consumption around the world (Avila 2018; InterAmerican Development Bank (IADB) 2011a). Indigenous communities living near wind farms in the Global South challenge governments and businesses' visions of distributive justice because these communities lack access to affordable electricity and basic infrastructure, such as purified water and sanitation (INEGI 2016).

The inequitable distribution of environmental costs means that certain communities experience more environmental risk than others (Maher 2018; Schlosberg 2013). For the people living close to them, wind farms pose many environmental risks, including visual landscape changes, noise, sleep disturbance, and land ionization (Romero et al. 2017) (the latter is a phenomenon in which electricity seeps into the land, which negatively impacts livelihoods (Pierpont 2009). While indigenous peoples are affected by environmental risks from wind energy, businesses obtain government economic incentives and are internationally recognized for their contributions to regional development and the fight against climate change (FEMSA 2011; Vestas 2019).

The justice of recognition acknowledges individuals' rights, values, cultures, and knowledge systems (Lecuyer et al. 2018). In the Global South, it is unclear how democratic governance recognizes and instrumentalizes indigenous peoples' rights to participate as equal partners at every level of decision-making in renewable energy investments (del Razo 2016; Environmental Justice / Environmental Racism 1991). A critical ethical dilemma surrounding the justice of recognition is how to evolve from political and business exclusion to integration of 
indigenous communities in the process of planning and developing renewable energy projects (Zografos and Martínez-Alier 2009). A key foundation of this dilemma is the question of why indigenous communities were "devalued" (Schlosberg 2013) and excluded in the first place.

Procedural justice is the implementation of fair and equitable institutional processes with regard to environmental management (Lecuyer et al. 2018; Urkidi and Walter 2011). Businesses and governments are expected to consult local communities in a nondiscriminatory way and attain consent for wind energy investments that might affect indigenous peoples' livelihoods (Urkidi and Walter 2011). Scholars argue that class, caste, ethnicity, and gender all prevent individuals from fully participating in decisions affecting their lives (Urkidi and Walter 2011). The failure to consider indigenous peoples' values, norms, behaviors, and beliefs is reported to be at the center of many free, prior, and informed consent (FPIC) disputes that have led to social unrest (Dunlap 2017a).

As presented above, the literature reveals indigenous peoples' claims and conflicts derived from environmental (in)justices (Avila 2018). Sustainable and renewable investments often display the same patterns of violence as those observed in extractivism: repression, criminalization, violence, death, and murder (Graff et al. 2019). Although EJ scholars discuss the dynamics of subjugation in postcolonial countries in relation to EJ's tenets (e.g., Schlosberg 2013), we still have little understanding of the consequences of wind energy investments in institutional contexts in which businesses and governments do not respect the basic principles of human rights and laws or indigenous peoples' norms and customs. In postcolonial countries, the social structure in relation to access to resources (distributive justice), participation in decisionmaking procedures (justice of recognition), and compliance with laws and regulations (procedural justice) is illustrated by the unacceptable outcomes of wind energy investments such 
as the assassination of human rights defenders seeking EJ (Avila 2018).

These issues lead to the study's research question: "What are the consequences of wind energy investments at the Isthmus of Tehuantepec?" To discuss this question in the context of enacting EJ's tenets in wind energy investments, I developed a qualitative study of wind energy investments in Mexico as presented in the following section.

\section{Methods}

I performed a qualitative longitudinal study that systematically followed a contentious wind energy project in Mexico from its failed attempt at construction in 2013 to its inauguration in 2019. In 2013, newspapers in Mexico and Denmark reported protests by the Zapotecas and Ikoots at the Danish Embassy and the headquarters of Danish wind energy firm Vestas against the imminent construction of the Mareñas Renovables wind farm on the Isthmus of Tehuantepec. My interest in this study is grounded in my personal relation to the Zapotecas as my father is Zapoteca. I acknowledge that my family connection to the Zapotecas might influence my research design, findings, and interpretations. However, I implemented the following strategies to attenuate this influence (Langley and Klag 2017): the systematic collection of empirical material and the diversity and triangulation of material sources.

I systematically collected empirical material for seven years (2013-2019). From 20132015, I engaged in desk research to identify key actors in the Mareñas Renovables project. Over time, this longitudinal study evolved from the Mareñas Renovables project to the challenges in enacting EJ's tenets in wind energy investments. These concerns were the focus of the further empirical data I collected from 2016 to 2019, which gave me the opportunity to write ethnographic field notes while conducting the research in Mexico, Denmark, Germany and 
Switzerland. In the findings section, I present vignettes (descriptive accounts) extracted from my ethnographic notes, which contain my experiences conducting this research (Jarzabkowski et al. 2014).

From 2013 to 2019, I systematically downloaded approximately 1,000 news reports from Mexico and Denmark on wind energy. I consulted 17 webpages, which I monitored and obtained information from online videos of indigenous peoples' protests, and I also joined their Facebook pages. I read 52 reports on wind energy firms' sustainable investments, United Nations observations of business and human rights media reports, and non-governmental organizations (NGOs) reports on wind energy in Mexico. I logged scholars' observations reported in academic journals and triangulated them with my empirical material. Based on this desk research, I identified themes related to challenges in enacting the tenets of EJ, i.e., distributive, recognition, and procedural (e.g., Schlosberg 2013), in addition to the transformation of the Isthmus of Tehuantepec region due to wind energy investments.

Although I have family members living in Juchitán, Oaxaca (the head municipality of the Isthmus of Tehuantepec region), obtaining access and consent to develop the fieldwork was one of the most challenging aspects of this research. On my first visit to Juchitán in May 2013, I failed to develop interviews with resistant Zapotecas and Ikoots against the Mareñas Renovables project. I represent a business school from Europe, and this identity held negative connotations when I approached the Zapotecas and Ikoots to develop my research. A female leader of a communal assembly told me, “... but you represent the firms ... and you work in a business school ... we do not talk to these people and we do not want to do anything with them" (Ethnographic notes, May 2013). Several times, I needed to explain that I was not working for any particular European wind energy firm. Thus, I asked family members in Juchitán to contact 
the organizers of the aforementioned protests at Vestas and the Danish Embassy on my behalf. I was invited to talk to these leaders in October 2013. I obtained verbal consent to develop fieldwork on the Isthmus of Tehuantepec after explaining to the indigenous communities that the purpose of my research was fully academic. From 2013 to 2014, I engaged in conversations with the indigenous communities to learn about their motives and the organization of the protests. From these conversations, I learned that indigenous peoples have a "culture of activism." Further, from 2015 to 2019, I engaged in in-depth interviews, conversations, focus groups, and participant observations with various relevant individuals and indigenous people communities at the Isthmus of Tehuantepec.

I carried out four participant observations (in 2013, 2014, 2017, and 2018), which took place over a total of 26 days. The observations occurred at assembly and weekly meetings at different locations on the Isthmus of Tehuantepec. Four focus groups were held with members of the Assembly of Indigenous Peoples at Juchitán and San Mateo del Mar. The length of the focus groups ranged from 30 minutes to two hours. Twenty-seven in-depth interviews and conversations (2013-2019) were conducted in Mexico City, Genève, Copenhagen, and Hamburg with government officials, wind energy business leaders, and NGO representatives to identify Mexico's national plan for wind energy and businesses' strategies for investing in wind energy projects. I did not write a protocol for the collection of the empirical material; however, the fieldwork evolved based on the three EJ tenets presented above because these themes were discussed in all my interactions, which lasted from 15 minutes to two hours. Given the sensitivity of the issues involved in wind energy investments, such as assassinations and threats, I was not allowed to record my conversations or semi-structured interviews. However, I took notes in all my interactions, which I transcribed after each meeting. 
I was unable to hold face-to-face or phone conversations with the co-owner of the Mareñas Renovables project or with the Danish firm Vestas, which is responsible for building the wind farm. A recurring response from these firms and investors' executives was "the conflict is still ongoing, so we cannot talk about it" (Ethnographic notes, May 2014). However, I had a conversation with a senior manager of the Dutch fund PGGM, which invested in the original Mareñas Renovables project. From 2013 to 2015, I was unable to reach a particular Zapoteca leader, who is anonymized in this paper as Ms. Mercedes, in the movement against wind energy investment in Mexico because she was in hiding due to death threats. However, in 2016, during the United Nations Human Rights Forum in Genève, Switzerland, I managed to converse with her, which was followed by a second conversation in January 2017 in Juchitán, Oaxaca.

\section{Analysis}

I organized the empirical material in the NVivo 11 database and triangulated it with previous research on the indigenous peoples of the Isthmus of Tehuantepec (Avila-Calero 2017; Campbell et al. 1993; Dunlap 2017a, 2017b, 2018a, 2018b; Juárez-Hernández and León 2014; Quintana 2015; Rubin 1994, 2004). Triangulation prevented me from reporting presumptions and misinterpretations of the current conflict in relation to the wind farms on the Isthmus of Tehuantepec.

I began analyzing the empirical material by developing a temporal narrative and constructing a timeline of events in relation to wind farm development on the Isthmus of Tehuantepec (Langley and Klag 2017). I aimed to identify critical events that helped me to understand the context of my research in relation to indigenous peoples' vision of justice. Subsequently, I wrote a synopsis of each critical event and identified themes (see Table 1). 
Given the limited space in this manuscript, these synopses are not presented; nevertheless, they helped me to refine my initial outline of the critical events with the feedback received from my informants. Thus, I present my findings as accurate reflections of the experiences of Zapotecas and Ikoots in relation to wind energy investments together with my experiences conducting this research. On January 15, 2014, I met a Mexican government official who read a teaching case entitled Vestas and the Indigenous Communities in Oaxaca, Mexico: Clean Energy gets Messy (Ramirez and Vester 2013), which was written based on my research, and this official commented "... you should change the title of the case and stop presenting this type of issue to your students" (Ethnographic notes, January 2014). The field work developed because I had the opportunity to 1) visit the Isthmus of Tehuantepec region and talk to Zapotecas and Ikoots and 2) hold interviews with government and business representatives in their offices in Mexico and Europe. Doing so helped me to understand the complexities of the visions and responses of the indigenous peoples seeking justice in the Isthmus of Tehuantepec region and the government's and businesses' vision for wind energy investments.

[Insert Table 1 about here]

The empirical puzzle that captured my attention evolved from the assassination of defenders of Zapotecas and Ikoots' territories to the emergence of indigenous peoples' roles in seeking EJ. To transition from analysis to abductive inference, I reflected on my findings in relation to the institutional contexts of my research to explain and expand my understanding of EJ's tenets. To investigate my observations with the empirical material collected based on the synopses I had written, I wrote detailed descriptions of my ethnographic work. These descriptions provided the grounds for me to relay my refined initial findings and contextualize the "fight" of the Zapotecas and Ikoots against wind energy investment. I clustered the 
statements collected into a summary of themes (see Table 2): 1. Dysfunctional institutional context; 2. Businesses' conflicting ethical behavior regarding EJ's tenets; and 3. Seeking environmental justice (EJ).

[Insert Table 2 about here]

Finally, I returned to the materials I had collected in this longitudinal study to further analyze them in relation to the government and businesses involved in wind energy investments, EJ's tenets, and the role of indigenous peoples seeking justice. This process was interactive, and I started at the micro-level of the response of indigenous people, the government, and businesses to wind energy investments. This process allowed me to 1) unpack a feature rarely disclosed regarding wind energy investment in the EJ literature: the gradual and continuous transformation of indigenous peoples' norms and behaviors; and 2) propose a conceptual understanding of the social turbulence of environmental (in)justice. This concept provides the basis for the EJ conceptual framework comprising the discussion and contribution of this study.

\section{Findings}

I present the findings in a composite narrative taken directly from ethnographic field notes, conversations, observations, interviews, and secondary data sources. The three themes in Table 2 are each presented, starting with the dysfunctional institutional context of this research.

\section{Dysfunctional institutional context}

To illustrate the institutional context of my research, I present a vignette from my first field trip to the Isthmus of Tehuantepec region.

Vignette 1: Dysfunctional institutional context (Isthmus of Tehuantepec, Oaxaca, May 
In 2013, I undertook my first field trip to the Isthmus of Tehuantepec, Mexico. Before embarking on the four-hour drive from Tuxtla Gutierrez, Chiapas to Juchitán, Oaxaca (the head municipality of the Isthmus of Tehuantepec), I received some advice for the journey: "Don't drive after dark," "Don't stop in isolated places," and "Don't ask for help from the local police ..."

I was still 45 minutes from Juchitán, driving a rented light pickup truck down an isolated, windy road when dusk set in. I began to feel anxious about the possibility of something bad happening. I thought about the assassinations I had read about in my desk research back home (Copenhagen). Some had taken place along this same road by the wind farms looming up ahead. Héctor Regalado Jiménez, a member of the Asamblea Popular del Pueblo Juchiteco (APPJ), had been assassinated just a few months before after opposing the construction of a wind farm, Bii Hioxho, which was being constructed by the Spanish firm Gas Natural Fenosa (Kaos 2013). Mr. Regalado Jiménez was shot six times by hitmen accompanied by local police. Incredibly, no one has ever been incarcerated or even charged for this crime (Blog SIPAZ 2013). To me, this crime epitomized the lawlessness in this region and the impunity of those involved.

I continued my journey. Soon, I crested the top of a hill, which exposed me to an unforgettable scene: bright, flashing red lights in the distance and the huge shadows of colossal wind turbines. It felt like a dream or a science fiction movie — arriving in a futuristic interstellar city. I woke from this dream quite abruptly as I neared the wind farms, passing unpaved roads, houses lit with candles, and chaotic intersections lacking traffic lights. 
Based on the above facts and narrative, I termed the institutional context of my research "Dysfunctional" (see Table 1). Outwardly, Mexico has transitioned its institutional context through constitutional change and the promulgation of laws and regulations, although at the same time, the Mexican government cannot adequately provide a rule of law or a climate of peace for civil society. Impunity, corruption, and the inability of local, state, and federal governments to provide physical security, peace, and justice to civil society characterize the context of this research. My desk research revealed that the Mexican government, wind energy developers, and businesses investing in wind farms in this region argue that transforming unproductive land through the installation of wind turbines will bring jobs, investment, and development. However, the reality differs somewhat from this argument as I present below.

\section{Institutional transition}

Mexico initiated an institutional transition in the 1990s to make its energy sector more efficient and sustainable (e.g., Zárate-Toledo et al. 2019). In 1992, constitutional reform transformed the law on public service electricity, Ley del Servicio Público de Energía Eléctrica (LSPEE). As well as promoting renewable energy, this reform allowed the private sector to generate electricity for consumption and/or sale to third parties. In 1994, the first wind farm-La Venta I, which consisted of seven 225 KW Vestas wind turbines (Gómez 2009)—was established in a town in the Isthmus of Tehuantepec region called La Ventosa (which translates as "The Windy"). The Isthmus of Tehuantepec region has the most wind resources in Latin America according to the Wind Resource Map of Oaxaca (Elliott et al. 2004). The area of San Mateo del Mar has exceptional wind resource potential; it is estimated to have Class 7+ wind resources, with a measured wind power density of $>800 \mathrm{~W} / \mathrm{m}^{2}$ at $50 \mathrm{~m}$ at location 3 (see Figure 1). 
[Insert Figure 1 about here]

In November 2008, Mexico established the "Law for the Use of Renewable Energy and Financing of Energy Transition" to refine the existing laws regulating private investment in renewable energy projects. Changes to the Mexican Constitution in 2011 recognized the right to consultation, and Article 2, section IX states the following: "Consult indigenous peoples in the preparation of the National Development Plan at the state and municipal levels" (Cámara de Diputados and Congreso de la Unión 2011, p. 4). In 2013, the Mexican energy reform was established. The energy reform aims to increase renewable energies and facilitate private investment in energy in Mexico. In 2014, a package of laws governing Mexico's energy sector for private investors came into force. The new laws stipulated that businesses must inform both landowners and the Mexican Energy Secretary of their proposed plans for energy investments. Further, businesses must engage in a consultation process with local communities that might be affected by their investments. Business representatives can then negotiate with the landowner to determine whether land will be bought, leased, or subject to temporary use, as well as what the owner will receive in exchange (Terwindt and Schliamann 2017). However, many businesses investing in wind energy have been involved in disputes with indigenous peoples, which are presented in the following section.

\section{Businesses' conflicting ethical behaviors regarding EJ's tenets}

In 2019, the Isthmus of Tehuantepec was home to 28 wind farms, with a total of 1,583 turbines ranging from 33 to 110 meters high. These wind parks generate 2,756 MW of electricity (Asociación Mexicana de Energía Eólica (AMDEE) [Mexican Wind Energy Association] 2019; Noticias del Istmo 2019; Secretaría de Energía 2018). Zapotecas and Ikoots claim that wind 
farms have been constructed in the region since the 1990s without 1) considering the fair distribution of costs and benefits; 2) recognizing the basic principles of human rights or respect for the environment; or 3) implementing existing laws and conventions (Field notes, October 2013 and December 2014). To illustrate these concerns, I present the example of the Mareñas Renovables wind energy project below.

\section{Mareñas Renovables wind farm project}

The Mareñas Renovables project was a wind energy investment started in 2004 by the Spanish renewable energy developer Preneal (McGovern 2012). In February 2012, Preneal sold its affiliate in Oaxaca to the Mareñas Renovables consortium, which was owned by the Mexican firm FEMSA, the Macquarie Infrastructure Fund Mexico (FIMM), Mitsubishi Corporation, and the Dutch pension fund PGGM (Preneal 2011). The Inter-American Development Bank (IADB) approved a loan of \$72 million USD to help finance the construction of the 396-megawatt wind farm (Inter-American Development Bank (IADB) 2011a). In March 2012, Vestas announced it had signed a contract to provide 132 V90-3.0 MW turbines for the wind park project (State of Green 2012). A press release from Vestas stated the following:

This is a very important milestone for Vestas, as we look to strengthen our leadership position in Latin America and globally. We are truly committed to the development of wind energy in Mexico and are extremely proud to bring a clean, competitive and predictable energy source to Mexico, while contributing to the creation of local highquality jobs and competencies (Renewable Energy Magazine 2012).

The Mareñas Renovables wind farm project, which was the subject of ongoing dispute, is presented below in relation to EJ's tenets. 


\section{Distributive justice}

In 2013, the multinational enterprise Vestas attempted to begin building the Mareñas Renovables wind farm. The company planned to install 102 wind turbines on the Barra Key and a further 30 in Santa María del Mar, which is located in San Mateo del Mar (see Figure 2). This attempt led to disputes among indigenous peoples, Mareñas Renovables representatives, and government officials. The indigenous people elaborated as follows:

Wind farms have contaminated lagoons with fuel waste, which has affected fishing. It is clear that large foreign companies, such as Iberdrola or Vestas Wind Systems, have earned millions in profits at the expense of our land (Conversation-Representative of the Communal Assembly at Juchitán, October 2013).

[Insert Figure 2 about here]

In 2013, the opposition of the Zapotecas and Ikoots people to the Mareñas Renovables project was focused on concerns about ecological destruction (Focus groups, October 2013). Zapotecas and Ikoots argued that installing 132 V90-3.0 MW turbines on the Barra Key would have an adverse "environmental impact" on indigenous peoples' economic activities (Focus groups, October 2013). The Barra Key is located between the Laguna Superior (Upper Lagoon) in the municipality of San Dionisio del Mar and the Laguna Inferior (Lower Lagoon) in the municipality of San Mateo del Mar (see Figure 2). Fishermen explained their concerns and livelihoods:

We live off catching shrimp at the Laguna Inferior [Lower Lagoon]. The shrimp eat from the leaves that fall from the trees at the Barra [Key]. If they [wind firms] install these ventiladores [wind turbines], there will be no more trees ... and so, no more shrimp ... (Conversation-Fisherman in San Mateo del Mar, October 2013). 
My wife goes to the market every day to sell fish and shrimp caught by me ... She has better skills as a merchant. Even though my wife didn't finish elementary school, she is very clever at math ... no one runs afoul of her ... (Conversation—Fisherman in Huamúchil, Oaxaca, December 2014).

Narratives collected on the Isthmus of Tehuantepec describe attacks by armed paramilitary forces on indigenous communities defending their territory. Zapotecas and Ikoots have witnessed both threats and physical violence in relation to wind energy investments: death threats in person and by phone, guns fired in front of their homes, and attempted kidnappings and assassinations (Focus groups, December 2014; Interviews, January 2017).

Human rights concerns evolved as costs for Zapotecas and Ikoots from wind farms investment. Zapotecas and Ikoots women are sexually abused by foreign engineers who come to work on energy wind farms (Dunlap 2018a, interviews at the Isthmus of Tehuantepec, Oaxaca, January 2017).

Given the social unrest, the Mareñas Renovables wind farm was terminated by an Oaxaca state judge in 2013. Nevertheless, the project was resumed in 2015 after being renamed Eólica del Sur.

In a follow-up focus group in 2015, indigenous communities presented more sophisticated arguments in relation to the cost of development:

The biggest environmental impact of wind power is evident to the naked eye. As wind farms grow, a country needs to pay more attention to the landscape and to environmental, historical, cultural and tourist-related impacts (Conversations - indigenous people in San Mateo del Mar, September 2015).

I discussed my initial findings with Mr. Dante Pesce, a member of the United Nations 
Working Group on human rights, who commented as follows:

... it is the cost of development. [Mexican] society and government officials seem to live on different planets - in particular, the political elites, they [government representatives] do not have anything in common with indigenous people (Interview-member of the UN Working Group on human rights, Genève Switzerland, November 2016).

The above findings present the negative impacts of wind energy investments in the Isthmus of Tehuantepec. I discuss the implications in the region in the following vignette: Vignette 2: Indigenous peoples' conflicting visions of mother earth (Isthmus of Tehuantepec, Oaxaca, October 2017) In October 2017, I drove approximately 73 km from Juchitán to Huamúchil, a town of approximately 2,000 inhabitants located $15 \mathrm{~km}$ from San Dionisio del Mar (see map 2). I was impressed to see state-of-the-art wind turbines situated along the unpaved roads to my destination. I became intrigued by the fact that close to the wind farms, there were relatively new houses equipped with air conditioners, which is not common in the Isthmus of Tehuantepec region. In Huamúchil, approximately $90 \%$ of the residents live off fishing at Laguna Superior [Upper Lagoon]. Local residents shared with me their struggles with division among their community. Some members of the community support wind farm investments as wind energy developers offer them benefits, such as free access to medical tests, cash payments, and material to build or rebuild their homes. I enquired with a local resident regarding my observation of "better houses" along the wind farms. I recorded the explanation in my ethnographic notes as follows: ... well some people have leased their lands, I don't know how much they get paid, but now they do not work. They are hamaqueros, which means they don't work in 
agriculture, fishing or commerce ... they simply sleep in their hamacas [hammock] and wait for the monthly payments they receive from wind developers (conversations, October 2017).

In contrast to these "hamaqueros," many residents at Huamúchil and other communities I visited on the Isthmus of Tehuantepec reject wind farm investments; consequently, they do not receive the aforementioned monetary and nonmonetary compensations. Zapotecs and Ikoots who accept and reject wind farm investment are in conflict with one another over the land dispute.

As presented in the above vignette, "hamaqueros" is a term that has gradually emerged in the Isthmus of Tehuantepec since 2000 when leasing land appeared to become more common. To hamaqueros, leasing land seems more attractive than fishing or agriculture (Field notes from fieldwork at the Isthmus of Tehuantepec, December 2014; October 2017). A local resident explained as follows:

The price of shrimp and fish has been unstable in the last couple of years. Sometimes we believe it is not worth waking up at 3 am to catch shrimp in relation to the pay we get ... this is why some compañeros [members of our cooperative] prefer leasing their lands to wind energy developers and stop working as our ancestors have taught us ...

(Conversation-Fisherman in Huamuchil, Oaxaca, October 2017).

I further enquired about the implications of the "hamaqueros" term to the manager of a wind energy firm, who explained as follows:

... we hear local people say that "you have to work; renting your land is not your main income." It is not our responsibility to instruct hamaqueros what to do with the money. However, we spend much time trying to make the hamaqueros understand they have 
leased their lands, so they cannot enter freely into shepherding animals, for example, cows (Interview-manager at a Wind Energy firm in Mexico City, May 2018).

During each visit to a wind farm in the Isthmus of Tehuantepec region, I observed armed guards securing access to the premises. On some occasions, I was denied permission to even approach the main gate of the wind farm let alone enter the farm and take pictures. I simply heard from the distance the noise of the turbines' blades (Observations, January 2017). In conversations with indigenous people, I enquired about the gradual changes in the region derived from wind energy investment. Below, I present an extract from my field notes

Worrisome aspects of the gradual transformation of practices include 1) forcing indigenous girls to marry to allow wind energy investors access to communal land (e.g., Dunlap 2018a, conversations in Huamúchil, October 2017) and 2) the assassination of human right defenders (Coversations, Juchitán, January 2017).

\section{Justice of recognition}

The desk research I conducted (2013-2015) revealed that wind energy investors in the region organized events in public places to present and discuss the "myths and reality of wind energy" with local people, and sponsored public seminars on the benefits of wind farms (Websites - wind energy firms). A recurrent statement of the Zapotecas and Ikoots concerning the above initiatives is presented in the following quote:

... their "capitalist model" failed to consider "the spiritual and social" ties between the indigenous rural communities and the land (Focus groups in Juchitán and San Mateo del Mar, October 2013).

The following vignette presents indigenous peoples' approach to fighting for recognition. Vignette 3: Businesses' conflicting ethical behavior (Isthmus of Tehuantepec, Oaxaca, 
October 2013)

Over the years that I have driven in the Isthmus of Tehuantepec region, it has always captured my attention that the wind farms are named in local indigenous languages. The Mareñas Renovables project name is derived from Ikoots, who are known as mareños in Spanish. A local indigenous person commented that "wind energy firms think naming their investments with our local languages will bring them close to us. However, they do not know us" (Conversation in San Mateo del Mar, October 2013). I was surprised to read Inter-American Development Bank reports stating that consultations with local communities regarding the Mareñas Renovables project in 2011 were conducted in Spanish (Inter-American Development Bank (IADB) 2011b). A Mexican government official commented that in 2014, owners of the Mareñas Renovables project brought a mediator to the region to resolve the dispute. The mediator spoke neither Spanish nor the languages of the local indigenous peoples.

The above account illustrates the lack of recognition of the rights of indigenous peoples, who historically have been at a disadvantage in relation to government officials and business representatives, to participate in decision processes that affect their territories (Campbell et al. 1993). My findings indicate that indigenous peoples are only consulted in relation to regional development and investments after agreements have been negotiated between business and governments (Avila 2018; Zárate-Toledo et al. 2019), leading to such consultations being deemed theatrical by indigenous peoples (Dunlap 2017a; PODER 2015; conversations in Juchitán, January 2017). Nevertheless, Zapotecas and Ikoots have successfully and publicly preserved their culture and traditions (Rubin 1994, 2004), including their indigenous languages, foods, and clothing. For example, the traditional Tehuana dress, which consists of a velvet top 
embroidered with brightly colored flowers and a cotton skirt that falls to the feet, is still worn daily by women on the Isthmus of Tehuantepec. The recognition of the Zapotecas and Ikoots' culture and traditions has been a source of conflict in consultation processes, which is presented in the following section.

\section{Procedural justice}

The institutional processes of the state, other than environmental management, are defined in this research as 1) inclusion in the decision-making process in wind energy investments in the form of consultation; and 2) fair enactment of the rule of law in protecting the physical security of indigenous peoples. Based on this procedural understanding, Zapotecas and Ikoots argue that the Mareñas Renovables project was approved by the Mexican government and financed by the Inter-American Development Bank (IADB) (2011b) without properly following the consultation statutes of the Indigenous and Tribal Peoples Convention (169 ILO). Zapotecas and Ikoots stated the following:

We did not have any dialogue with businesses in relation to the distribution of the wind energy benefits derived from the project [Mareñas Renovables] (Focus groups in San Mateo del Mar, December 2014).

The IADB's own reports acknowledge Zapotecas and Ikoots' claims. For example, the IADB Environmental and Social Management Report (ESMR) stated in section 64:

...to date [2011], the consultation process did suffer from a lack of a systematic process to register issues, concerns and feedback of affected people ... (Inter-American Development Bank (IADB) 2011b, p. 28).

However, a senior IADB executive made the following comment: 
Consultations were conducted in compliance with Mexican law and the bank's directives. We subcontracted this process to a local [Mexican] consulting firm. To be honest, I do not know the details of the procedure ... but you know how these people operate ... We acknowledge there are some problems, but we are fixing them (Interview-Executive at the IADB's European branch, Hamburg, Germany, November 2013).

The statements above reveal the improper implementation of the existing institutional procedures in Mexico. To understand indigenous peoples' perception of the consultation processes that took place, I developed a focus group with representatives of the communal assemblies. Below, I present an extract from a conversation:

Opposition to wind projects has not so much to do with being against the generation of clean and renewable energy, but rather how projects are imposed without considering the decision of the population, the impact and the effects that they can cause, and the benefit and use to be made of the generated energy: "we are not against the technology to generate energy through renewable sources, but we reject its use in favor of the mere profit of the companies and to the detriment of the peoples and of our biocultural heritage" (Focus groups in Juchitán and San Mateo del Mar, December 2014). Indigenous peoples have developed different strategies for seeking justice in relation to the environmental (in)justices presented above. This argument is presented in the following section.

\section{Seeking environmental justice (EJ)}

In order to illustrate indigenous peoples' strategies in seeking EJ, I present the following vignette: 
Vignette 4: Resilience in seeking environmental justice (Genève, Switzerland, November 2016)

In 2016, at the UN Human Rights Forum in Geneva, I had a conversation with a Zapoteca human rights defender, who is anonymized in this paper as Ms. Mercedes. I noticed that during the conference (in the coffee breaks), Mexican governmental officials were trying to talk with Ms. Mercedes in relation to wind farms on the Isthmus of Tehuantepec. A Mexican governmental representative spoke to me regarding their attempts to talk with Ms. Mercedes: "She is stubborn, as she does not want to change her approach to wind energy investments ... it is foolish to think that their movement will change the [Mexican] government and [wind energy] businesses' agendas ...” In response to such comments, Ms. Mercedes replied, “we know our rights.” Ms. Mercedes gave me a document, Voces de Tierra, Mar y Viento [Voices of Earth, Sea and Wind], which raises questions about the wind farms in her region. Ms. Mercedes explained that their movement proposes, among other issues, to "revert the authorization granted by the [Mexican] energy secretary to build the infrastructure that will trigger the second phase of wind expansion [on the Isthmus of Tehuantepec], as it was given without considering the existing laws and conventions on the consultation process, for example." However, for the first time in the history of Mexico, between 2014 and 2015, a series of public consultations was developed in relation to the Mareñas Renovables wind farm, renamed Eólica del Sur. Zapotecas and NGOs' observers argued that since the beginning of the consultation process in October 2014, there were procedural defects, unilateral decisions, and state protagonists who used nondemocratic methods of authoritarianism and commercialization (PODER 2015, conversations in Juchitán, January and October 2017). Controversies in the 
procedural process of the Eólica del Sur wind farm project prompted the Dutch pension fund PGGM to cancel its participation in the investment in 2016. An executive from PGGM explained to me that the motivation for PGGM's "adventure in Mexico," as she described it, was to invest pension money in green energy projects. The PGGM executive commented as follows: PGGM trusted that all stakeholders in the project followed standard procedures for constructing the wind farm. However, this project is too controversial ... so we decided to leave (Conversation-PGGM executive at the UN Human Rights Forum, Genève Switzerland, November 2016).

I observed how the PGGM executive shrugged her shoulders and, with a smile that I interpreted as shame, commented, "Yes, it is a pity what happened in Mexico, but we learned." In January 2017, I made another field trip to the Isthmus of Tehuantepec. I followed up with Ms. Mercedes regarding her arguments at the UN Human Rights Forum in relation to selfdetermination, the negative environmental impacts of wind farms, and the assassination of human rights defenders. When I returned to Mexico City after this field trip, I had a conversation with an official from the Federal Government of Mexico. The official advised me to discontinue my field research in that region. He said of the Isthmus of Tehuantepec, "It is unsafe ... land disputes have escalated out of our hands" (Conversation, Mexico City, January 2017).

Ms. Mercedes might speak on behalf of indigenous peoples and women in Mexico and internationally, but she considers herself simply a member of the women's mobilizations and organizes public protests organized together with men on the Isthmus of Tehuantepec, all of whom demand justice.

Among the demands put forward by organizations and communities opposed to wind megaprojects are the cessation of criminalization, threats, and aggressions against human 
rights defenders and the territory (Blog SIPAZ 2013).

The reality of the enforcement of institutional state processes is demonstrated as follows. The Asamblea de Pueblos del Istmo en Defensa de la Tierra y el Territorio (APIDTT) [Assembly of the Peoples of the Isthmus in Defense of Land and Territory] sought the cancelation of the Eólica del Sur project through the Mexican Supreme Court by means of a "writ amparo"- a Mexican legal procedure for the protection of human rights (Mejorada 1946). On January 10, 2018, the National Supreme Court of Justice issued a ruling to exercise its power to recognize the writ amparo (Suprema Corte de la Nación 2018). In relation to the Eólica del Sur wind farm project, Mr. Rolando Crispín López, a member of the communal assembly at Alvaro Obregón, was assassinated on July 24, 2018 (Manzo 2018). Nevertheless, on November 14, 2018, the Mexican Supreme Court denied the writ amparo to the Zapotecas and Ikoots' indigenous peoples. The minister from the Supreme Court stated that it "complies with the condition that was carried out previously, because it was carried out as soon as possible, understanding that it is in the early stages of the project" (Business \& Human Rights Resource Centre 2018). Vestas (2019) was invited on March 28, 2019 to participate in the radio program "Orientering" at the Danish Radio station DR to discuss the Eólica del Sur project. Vestas declined the invitation. However, Mr. Anders Riis, head of media relations at Vestas, sent a press note stating: “... [Vestas] has not been presented any documentation of anything being wrong with our project in Mexico" (DR 2019). Thus, wind farms continue to be built at the Isthmus of Tehuantepec. On May 28, 2019, the Eólica del Sur wind farm, with 132 wind turbines installed over an area of 4,500 hectares in the Isthmus of Tehuantepec, Oaxaca, finally started operations with the capacity to generate 396 MW of electricity (Noticias del Istmo 2019). I had a conversation with one of the members of the consortium Eólica del Sur to learn what consent 
was reached with the indigenous people:

We agree with the indigenous people that Eólica del Sur will pay a portion of the electricity bill to the communities who live close to the wind park. I do not know exactly how much, but it will be shown on the electricity bill (Interview-Executive from a firm in co-ownership of the Eólica del Sur wind park, Mexico City, May 2019).

I had a WhatsApp conversation with a local resident in Juchitán, Oaxaca in relation to the agreement with Eólica del Sur, and they commented as follows:

It is too new, there are too many expectations and we are not sure how the bills will appear in reality. We need to wait and see if the promises will be kept (Whatsapp conversation—Juchitán resident, WhatsApp communication, June 2019).

While it may be too early to know if they will keep their promise, if the Eólica del Sur does distribute some of the benefits of the wind farm by paying a percentage of the indigenous peoples' electricity bills, it will be the first time for wind park in Mexico to do so.

\section{Discussion}

The findings presented show that Mexico is in a phase of institutional transition to attain a renewable energy system, with constitutional change and energy reforms to allow private investment in the energy sector. Nevertheless, the consultation process stipulated by this institutional change has been deemed theatrical by local communities (Dunlap 2017a; PODER 2015; conversations). I posit that the tenets of EJ may be insufficient for discussing environmental (in)justice when 1) there are diverse understandings of how to protect Mother Earth among indigenous peoples, businesses, and governments; and 2) there is a lack of understanding and acknowledgement of the dysfunctional institutional context. I assert that 
different visions of these tenets oppose the policies implemented by the Mexican government to allow private business investments in wind energy. These different visions in a dysfunctional institutional context suggest a gradual transformation of the norms and behaviors of indigenous peoples and conceptualize the social turbulence of environmental (in)justice. I present these arguments in the following sections.

\section{Gradual and continuous transformation of indigenous peoples' norms and behaviors}

This research highlights the gradual and continuous transformation of indigenous peoples' norms and behaviors owing to wind energy investments, first through the discovery of the hamaqueros - indigenous people who have moved away from their original economic and cultural livelihoods such as fishing or agriculture, and instead choose to receive payments from wind energy firms for leasing land—but also through more worrisome aspects, such as forcing indigenous girls to marry to allow wind energy investors access to communal land (e.g., Dunlap 2018a, interviews) and the assassination of human right defenders. Although this gradual and continual transformation process has been observed in environmental (in)justice research (Graff et al. 2019; Maher 2018; Urkidi 2010; Walker and Bulkeley 2006; Zárate-Toledo et al. 2019), I posit that this phenomenon offers a novel understanding of procedural justice and should be considered in the analysis of EJ's tenets in dysfunctional institutional contexts. EJ scholars discuss procedural justice in relation to class, caste, and ethnicity (Lecuyer et al. 2018). This study expands our understanding of class because hamaqueros appear to be an emerging class among indigenous peoples at the Isthmus of Tehuantepec. Hamaqueros who favor wind energy investments are included and listened to in the decision-making process and consequently receive access to the distributive benefits. At the same time, many indigenous people continue to 
fight the construction of wind farms, resulting in their exclusion from the consultation processes (PODER 2015; conversations). Resistance groups who want to stop the "development" of the Isthmus of Tehuantepec region are portrayed as retrograde. Indigenous peoples are divided, leading to conflict and social turbulence.

Resilience is another aspect studied by EJ's scholars (e.g., Schlosberg 2013; Urkidi and Walter 2011). In this research, resilience is underscored by the differing visions of the environment and justice held by indigenous peoples, governments, and businesses. For indigenous peoples, resilience is the tradition of fighting, resisting, and pursuing justice to defend their territories and preserve their languages, traditions, and customs, and they oppose the imposition of a different way of life and devise strategic means to delay it. For the hamaqueros, who accept the wind farms, resilience was observed through the fact that Eólica del Sur agreed to pay a percentage of their electricity bills, which is the first instance of such distributive justice in Mexico. Resilience of those who oppose the wind farms was also observed in this study because the Eólica del Sur was not built at the original site (Key Santa Teresa). For governments and businesses, resilience is working together by proposing and approving constitutional reforms to attract further FDI in renewable energy. The Mexican energy reform and the construction of the Eólica del Sur wind farm after a delay of more than six years are clear examples of government and businesses' resilience.

The context of the Isthmus of Tehuantepec helps us redefine our understanding of EJ's tenets in a way that goes beyond the normative ethical discourse of providing all individuals with sustainable energy (McCauley et al. 2013) to the protection of basic human rights such as the right to peace. Although the research setting on the Isthmus of Tehuantepec is unique, the struggle of the Zapotecas and Ikoots echoes the voices of many others who have been silenced 
by paramilitary forces in the defense of business investments (Avila 2018; Maher 2018). Indigenous people around the world, such as Ms. Mercedes, face constant threats, repression, oppression, and violation. Indigenous people highlight the conflict and climate disasters businesses are trying to reverse through renewable energy.

\section{Social turbulence of environmental (in)justice}

Governments and businesses hold contrasting views to indigenous peoples of what it means to protect Mother Earth (Escobar 1996). Government officials and business representatives promote wind farms as a technical solution to the environmental (in)justices that have been committed against Mother Earth (e.g., climate change), and a way to transform unproductive land into productive land (e.g., Inter-American Development Bank (IADB) 2018). Such investments produce much-needed electricity for businesses and realize sustainable energy goals (FEMSA 2017). On the other hand, to indigenous peoples, this "unproductive land" is Mother Earth. Indigenous people who oppose wind farms seek local and international legal assistance to reverse the gradual and constant (in)justices against them. Yet, despite the ongoing and active promotion of new and existing laws, international conventions, and regulations to protect indigenous peoples in energy investments, they are commonly not enforced owing to the dysfunctional dynamic that exists within governments and businesses in Mexico and other transitioning institutional contexts. This phenomenon is conceptualized in this research as the social turbulence of environmental (in)justice.

Two critical aspects of the social turbulence of environmental (in)justice concept are derived from dysfunctional institutional contexts. The first is an ethical dilemma based on the choice made by the Eólica del Sur consortium, and despite the facts that 1) the project was 
opposed; 2) human rights defenders were murdered; and 3) NGOs reported conflicting consultation processes (among other factors; see Table 1 and findings section), the Eólica del Sur wind farm was constructed and inaugurated in May 2019. The ethical dilemma applies not only to the businesses that have invested in the Isthmus of Tehuantepec region since the 1990s but also to government officials. Mexico was already home to many wind farms before the Mexican energy reform was approved in 2013. A debate in EJ (Peluso and Vandergeest 2011; Schlosberg 2013) is which comes first: a legal framework to secure EJ in investments such as in renewable energy or the investment itself. It might be naive for national and international investors in dysfunctional institutional contexts to rely solely on reports that support their investments to make ethical decisions about them, as these reports assume that 1) the benefits of the investments will be distributed; 2) indigenous peoples' rights will be recognized; and 3) the consultation procedures will abide by norms, customs, and laws. This study supports the limited research available on EJ's tenets in dysfunctional institutional contexts (Dunlap 2017a; Dunlap and Fairhead 2014; Gonzalez and Pérez-Floriano 2015; Hernández et al. 2017) that trigger social turbulence. In such contexts, businesses_-perhaps unintentionally—might be involved in an ethical dilemma of whether to invest. The second critical ethical aspect of the social turbulence of environmental (in)justice concept is the normality of armed paramilitary attacks in dysfunctional institutional contexts in postcolonial countries, which pose a latent threat to the survival of indigenous peoples (Dunlap 2018a). The mere presence of indigenous peoples on the Isthmus of Tehuantepec in postcolonial times could be called a testament to the human will to survive. Notably, many pragmatic strategies are employed by indigenous peoples to denounce such abuses (Maher 2019; Urkidi 2010) and social turbulence. These strategies can materialize as mobilizations or even physical confrontations against paramilitary groups. 
(In)justices regarding EJ's tenets are visible in this study through 1) the failure to enforce laws, international conventions, and regulations in wind energy investments and 2) the lawlessness in protecting indigenous peoples and their territories. The Mexican energy reform appears to follow a centralized top-down model of renewable energy (Weinrub and Giancatarino 2015; Zárate-Toledo et al. 2019). However, in this model, empowerment is given to private businesses and not to communities. As the findings show, indigenous peoples' understanding of EJ are based on respect for Mother Earth. However, it is also important to them that before an investment is approved by local and federal governments, their right to participate in decisionmaking is respected (Sikor and Newell 2014) and procedural EJ tenets, such as ILO Convention 169, are enforced. Many direct and indirect instances of repression, oppression, and violations against indigenous peoples by governments and businesses are presented herein. I posit that a business's ethical behavior is threatened even when indirectly involved in recognition, distribution, and procedural (in)justices, even if not directly executing human rights abuses (United Nations 2011). These problems highlight the implications for businesses and the future directions for research.

\section{Implications for business and future research}

The empirical material indicates that indigenous communities on the Isthmus of Tehuantepec are fighting government officials who have failed to enforce Mexican laws and regulations (Campbell and Green 1996). In the future, the ethical dilemmas concerning the promotion of wind power by national governments should be explored, with a focus on the various political structures of regional/local planning systems and how they could facilitate, for example, the participation of indigenous peoples in decision-making to secure their survival (Gellert and 
Lynch 2003; Toke et al. 2008). Ultimately, public policies allowing indigenous peoples to participate collectively and not simply as individuals are required to challenge differing environmental visions and enforce current laws and regulations.

This study has particular significance to me because it reveals my Zapotecas indigenous background. Nevertheless, my personal attachment is a limitation of this study. To verify the findings presented herein, other indigenous peoples or renewable energy investments in other postcolonial countries should be studied with regard to EJ's tenets. Further ethnographic studies could also examine how businesses and governments manipulate national laws and international conventions to facilitate investments in renewable energy, which ultimately allow them to report advancements in Agenda 2030 of the United Nations Sustainable Development Goals (2015). Nevertheless, researchers should exercise caution when dealing with dysfunctional institutional contexts in postcolonial countries because the social turbulence that materializes as threats and attacks is directed not only toward indigenous peoples but also to journalists, activists, and human rights defenders (Human Rights Council 2018). Another limitation of this research is that I could not gain access to the firm responsible for building the Eólica del Sur project because the company does not want to publicly discuss the project; therefore, I relied on secondary data. Future research should incorporate businesses' visions of EJ and discuss them in relation to indigenous peoples.

\section{Conclusions}

Drawing on a longitudinal study of wind farms on the Isthmus of Tehuantepec, I extend the existing literature on EJ tenets by discussing how the government acts as a strong facilitator for wind energy investment while failing to protect indigenous peoples' basic human rights and 
livelihoods. Businesses appear naive when building wind farms in dysfunctional institutional contexts by directly and indirectly becoming involved in (in)justices. Indigenous peoples, in their attempt to attenuate intimidation, rejection, and human right abuses, appear to be trapped by the social turbulence that exists in such dysfunctional institutional contexts. The concept of social turbulence extends the research on (in)justices regarding EJ's tenets and conflicts in postcolonial countries, wherein the assassination of human rights defenders appears to be institutionalized, as indicated by the steadily increasing number of cases.

\section{Compliance with ethical standards}

\section{Acknowledgements}

I appreciate the constructive guidance and encouragement provided by Sara Louise Muhr, Section Editor: Critical Studies and Business Ethics as well as three reviewers. I thank Ana María Munar, Kai Hockerts and the members of the Centre for Business and Development Studies (CBDS) at Copenhagen Business School (CBS) for their helpful comments on a previous paper draft. This article is dedicated to the Zapotecas, Ikoots, and other indigenous peoples around the world who continue to sacrifice their lives for the protection and sustainable development of Mother Earth.

\section{Ethical approval}

All applicable international, national, and/or institutional guidelines for the care and use of animals were followed. 


\section{Informed consent}

Informed consent was obtained from all individual participants included in the study. 


\section{References}

Altamirano-Jiménez, I. (2017). “The sea is our bread”: Interrupting green neoliberalism in Mexico. Marine Policy 80, 28-34.

Asociación Mexicana de Energía Eólica (AMDEE) [Mexican Wind Energy Association] (2019). Mapas Eólicos [Wind Maps], Retrieved March 6, 2019, from https://www.amdee.org/mapas-eolicos.

Avila-Calero, S. (2017). Contesting energy transitions: Wind power and conflicts in the Isthmus of Tehuantepec. Journal of Political Ecology 24(1), 992-1012.

Avila, S. (2018). Environmental justice and the expanding geography of wind power conflicts. Sustainability Science 13(3), 599-616.

Blog SIPAZ (2013). Oaxaca: Fallece Por Heridas de Bala Opositor a Proyecto Eólico de la Multinacional Gas Natural Fenosa, Retrieved December 22, 2017, from https://sipaz.wordpress.com/2013/08/06/oaxaca-fallece-por-heridas-de-bala-opositor-aproyecto-eolico-de-la-multinacional-gas-natural-fenosa/.

Business \& Human Rights Resource Centre (2018). México: Suprema Corte Niega Amparo a Comunidades y da Luz Verde a Proyecto de Eólica del Sur [Mexico: Supreme Court Denies Protection to Communities and Gives Green Light to Eólica del Sur project], Retrieved March 3, 2019, https://www.business-humanrights.org/es/méxico-supremacorte-niega-amparo-a-comunidades-y-da-luz-verde-a-proyecto-de-eólica-del-sur.

Calvano, L. (2008). Multinational corporations and local communities: A critical analysis of conflict. Journal of Business Ethics 82(4), 793-805.

Cámara de Diputados and Congreso de la Unión (2011). Constitución Política de los Estados Unidos Mexicanos, Retrieved November 11, 2011, from 
http://transparencia.uaz.edu.mx/documents/70010/ea9cb1cb-4cde-4c60-a50ce2d9ee4bb29b.

Campbell, H., Binford, L., Bartolomé, M. and Barabas, A. (1993). Zapotec struggles -histories, politics, and representations from Juchitán, Oaxaca. Smithsonian Institution Press, Washington, D.C.

Campbell, H. and Green, S. (1996). A history of representations of Isthmus Zapotec women. Identities 3(1-2), 155-182.

Del Bene, D., Scheidel, A. and Temper, L. (2018). More dams, more violence? A global analysis on resistances and repression around conflictive dams through co-produced knowledge. Sustainability Science 13(3), 617-633.

del Razo, C. (2016). A snapshot of the Mexican clean energy obligations system. Mexican Law Review 9(1), 81-90.

DR (2019). Radio Program Orientering, 28 February 2019. P1, Denmark, Retrieved March 3, 2019, from www.dr.dk/orientering.

Dunlap, A. (2017a). A bureaucratic trap: Free, prior and informed consent (FPIC) and wind energy development in Juchitán, Mexico. Capitalism Nature Socialism 29(4), 1-21.

Dunlap, A. (2017b). Wind energy: Toward a "sustainable violence" in Oaxaca. NACLA Report on the Americas 49(4), 483-488.

Dunlap, A. (2018a). Insurrection for land, sea and dignity: Resistance and autonomy against wind energy in Álvaro Obregón, Mexico. Journal of Political Ecology 25(1), 120-143.

Dunlap, A. (2018b). The 'solution' is now the 'problem:' wind energy, colonisation and the 'genocide-ecocide nexus' in the Isthmus of Tehuantepec, Oaxaca. The International Journal of Human Rights 22(4), 550-573. 
Dunlap, A. (2018c). Counterinsurgency for wind energy: The Bíi Hioxo wind park in Juchitán, Mexico. The Journal of Peasant Studies 45(3), 630-652.

Dunlap, A. and Fairhead, J. (2014). The militarisation and marketisation of nature: An alternative lens to 'climate-conflict'. Geopolitics 19(4), 937-961.

Elliott, D. L., Schwartz, M., Scott, G., Haymes, S., Heimiller, D. and George, R. (2004). Atlas de recursos eólicos del estado de Oaxaca [The Spanish version of wind energy resource atlas of Oaxaca]. Laboratorio Nacional de Energía Renovable, Oak Ridge, US.

Environmental Justice/Environmental Racism (1991). First National People of Color Environmental Leadership. 17 Principles of Environmental Justice. Washington, D.C., Retrieved October 20, 2013 from https://www.ejnet.org/ej/principles.pdf.

Escobar, A. (1996). Construction nature: Elements for a post-structuralist political ecology. Futures 28(4), 325-343.

FEMSA (2011). FEMSA y MMIF Adquieren Proyecto de Energía Eólica de 396 Megawatts, Retrieved November 11, 2013, from http://www.femsa.com/es/medios/femsa-y-mmifadquieren-proyecto-de-energia-eolica-de-396-megawatts/.

FEMSA (2017). Coca-Cola FEMSA, Retrieved December 20, 2017, from https://www.cocacolafemsa.com/index.html.

Gellert, P. K. and Lynch, B. D. (2003). Mega-projects as displacements. International Social Science Journal 55(175), 15-25.

Gobierno Federal (2012). Prospectiva de Energía Renovables 2012-2026 [Prospective of Renewable Energy 2012-2026]. Ciudad de México, Retrieved March 4, 2019 from https://www.gob.mx/cms/uploads/attachment/file/62954/Prospectiva_de_Energ_as_Reno vables_2012-2026.pdf. 
Gómez, L. B. (2009). El Mercado de la Energía Eólica en México’ ['The Wind-Energy Market in Mexico'], Oficina Económica y Comercial de la Embajada de España en Monterrey [Economic and Commercial Office of the Embassy of Spain in Monterrey], México.

Gonzalez, J. A. and Pérez-Floriano, L. R. (2015). If you can’t take the heat: Cultural beliefs about questionable conduct, stigma, punishment, and withdrawal among Mexican police officers. Organization Studies 36(5), 665-687.

Graff, M., Carley, S. and Pirog, M. (2019). A review of the environmental policy literature from 2014 to 2017 with a closer look at the energy justice field. Policy Studies Journal 47(S1), S17-S44.

Hernández, A. L., Cerami, A. D. U., Bartolo, F. R., Hernández, L. L. and Ceballos, X. R. P. (2017). Informe sobre la situación de las personas defensoras de los derechos humanos ambientales en México (2016). Ciudad de México. Centro Mexicano de Derecho Ambiental A.C. (CEMDA), Ciudad de México.

Human Rights Council (2018). Report of the Special Rapporteur on the Situation of Human Rights Defenders on his Mission to Mexico. Geneva, Retrieved February 9, 2019, from https://www.ohchr.org/EN/HRBodies/HRC/RegularSessions/Session37/_layouts/15/Wop iFrame.aspx?sourcedoc=/EN/HRBodies/HRC/RegularSessions/Session37/Documents/A_ HRC_37_51_Add_2_EN.docx\&action=default\&DefaultItemOpen=1.

INEGI (2016). Estadísticas a Propósito del Día Internacional de los Pueblos Indígenas. Datos Nacionales. Encuesta Intercensal 2015. Aguascalientes, Ags, Retrieved November 11, 2017, from http://www.inegi.org.mx/saladeprensa/aproposito/2016/indigenas2016_0.pdf. Inter-American Development Bank (IADB) (2011a). Eolica del Sur to Build Biggest Wind Farm in Mexico with IDB support, Retrieved March 6, 2019, from 
https://www.iadb.org/en/news/news-releases/2011-11-24/mexicos-marenas-renovableswind-farm\%2C9708.html.

Inter-American Development Bank (IADB) (2011b). Inter-American development bank Mexico Marena renovables wind power project (me-L1107) environmental category: A environmental and social management report (ESMR). Inter-American Development Bank, Mexico.

Inter-American Development Bank (IADB) (2018). Renewable energy, Retrieved June 20, 2018, from https://www.iadb.org/en/topics/energy/renewable-energy\%2C19008.html.

Jarzabkowski, P., Bednarek, R. and Lê, J. K. (2014). Producing persuasive findings:

Demystifying ethnographic textwork in strategy and organization research. Strategic Organization 12(4), 274-287.

Juárez-Hernández, S. and León, G. (2014). Energía eólica en el istmo de Tehuantepec: Desarrollo, actores y oposición social. Problemas del Desarrollo 45(178), 139-162. Kaos (2013). Fallece Opositor a Proyecto Eólico Que Fue Baleado Por Sicarios de Gas Natural Fenosa, Retrieved October 20, 2015, from https://www.windwatch.org/news/2013/08/07/fallece-opositor-a-proyecto-eolico-que-fue-baleado-porsicarios-de-gas-natural-fenosa/.

Langley, A. and Klag, M. (2017). Being where? Navigating the involvement paradox in qualitative research accounts. Organizational Research Methods 22(2), 1-24.

Lecuyer, L., White, R. M., Schmook, B., Lemay, V. and Calmé, S. (2018). The construction of feelings of justice in environmental management: An empirical study of multiple biodiversity conflicts in Calakmul, Mexico. Journal of Environmental Management 213, 363-373. 
Maher, R. (2018). Squeezing psychological freedom in corporate-community engagement. Journal of Business Ethics, 1-20. doi:10.1007/s10551-018-3898-y.

Maher, R. (2019). Pragmatic community resistance within new indigenous ruralities: Lessons from a failed hydropower dam in Chile. Journal of Rural Studies 68, 63-74.

Manzo, D. (2018). La Jornada: Asesinan a Rolando Crispín López, Activista de Pueblos Indígenas, la JORNADA, Retrieved September 16, 2018, from https://www.jornada.com.mx/2018/07/24/politica/014n1pol.

McCauley, D., Heffron, R. J., Stephan, H. and Jenkins, K. (2013). Advancing energy justice: The triumvirate of tenets. International Energy Law Review 32(3), 107-110.

McGovern, M. (2012). Developers Face Escalating Militant Opposition in Oaxaca, Windpower Monthly, Retrieved October 20, 2018, from https://www.windpowermonthly.com/article/1124476/developers-face-escalatingmilitant-opposition-oaxaca.

Mejorada, C. S. (1946). The Writ of Amparo. Mexican procedure to protect human rights. The Annals of the American Academy of Political and Social Science 243, 107-111.

Noticias del Istmo (2019). Inauguran en el Istmo el Parque Eólico Más Grande de América Latina. Noticias Del Istmo [The largest wind farm in Latin America is inaugurated on the Isthmus. News of the Isthmus], Retrieved 20 June, 2019, from https://www.noticiasistmo.com/2019/05/inauguran-en-el-istmo-el-parqueeolico.html?fbclid=IwAR0XEKXnbiPChuxBDO9TOwAXdzJKoVZ2LiB9whSe5JrLrd4jZjtATSMWus\#.XO3QtIHo6aM.facebook Peluso, N. L. and Vandergeest, P. (2011). Political ecologies of war and forests: Counterinsurgencies and the making of national natures. Annals of the Association of 
American Geographers 101(3), 587-608.

Pierpont, N. (2009). Wind turbine syndrome. A report on a natural experiment. King Printing, Lowell, Mass.

PODER (2015). Cuarto reporte de la misión de observación sobre el proceso de consulta indígena para la implementación de un proyecto eólico en Juchitán. Centro De Derechos Humanos, Oaxaca. Mexico.

Preneal (2011). Preneal Cierra la Venta de dos Proyectos Eólicos en Oaxaca (México), Retrieved October 13, 2013, from http://www.preneal.es/en/news/3-noticias/71-preneal-cierra-laventa-de-dos-proyectos-eolicos-en-oaxaca-mexico-por-89-millones-de-dolares.

Quintana, R. S. D. (2015). Energía Limpia o Energía Perversa: Actores Sociales y Parques Eólicos en Dinamarca y en el Istmo de Tehuantepec, Retrieved June 26, 2017, from https://consultaindigenajuchitan.files.wordpress.com/2015/01/2015-enero-robertodiego.pdf.

Ramirez, J. and Vester, T. (2013). Vestas and the Indigenous Communities in Oaxaca, Mexico: Clean Energy Gets Messy, Retrieved December 12, 2013, from http://www.thecasecentre.org/educators/products/view?id=119297.

Renewable Energy Magazine (2012). With 396 MW Order, Vestas is on the Rise in Latin America. Renewable Energy Magazine Wind, Retrieved October 13, 2013, from http://www.renewableenergymagazine.com/article/with-396-mw-order-vestas-is-on.

Romero, D., Montanyà, J. and Cancela, A. (2017). Behaviour of the wind-turbines under lightning strikes including nonlinear grounding system. Renewable Energy and Power Quality Journal 1(2), 439-444.

Rubin, J. W. (1994). COCEI in Juchitán: Grassroots radicalism and regional history. Journal of 
Latin American Studies 26(01), 109-136.

Rubin, J. W. (2004). Meanings and mobilizations: A cultural politics approach to social movements and states. Latin American Research Review 39(3), 106-142.

Schlosberg, D. (2013). Theorising environmental justice: The expanding sphere of a discourse. Environmental Politics 22(1), 37-55.

Secretaría de Energía (2018). Infraestructura Eólica en México Creció 300 por Ciento [Wind Infrastructure in Mexico Grew 300 Percent]: Pedro Joaquín Coldwell (PJC), Retrieved March 4, 2019, from https://www.gob.mx/sener/prensa/infraestructura-eolica-en-mexicocrecio-300-por-ciento-pjc.

Sikor, T. and Newell, P. (2014). Globalizing environmental justice? Geoforum 54, 151-157.

State of Green (2012). Vestas Wins Order for Largest Wind Energy Project in Latin America, Retrieved November 2, 2018, from https://stateofgreen.com/en/partners/state-ofgreen/news/vestas-wins-order-for-largest-wind-energy-project-in-latin-america/.

Suprema Corte de la Nación (2018). 10 Enero 2018, Lista Sesión Fallados, Datos Sensible, Retrieved October 18, 2018, from https://www.scjn.gob.mx/.

Terwindt, C. and Schliamann, C. (2017). Mexico's energy: A tale of threats, intimidation, and dispossession of indigenous peoples. In H. Böll (ed.), Tricky business: Space for civil society in natural resource struggles (pp. 46-51). ARNOLD Group Companies, Großbeeren, Berlin.

Toke, D., Breukers, S. and Wolsink, M. (2008). Wind power deployment outcomes: How can we account for the differences? Renewable and Sustainable Energy Reviews 12(4), 11291147.

United Nations (2011). Guiding principles on business and human rights. Implementing the 
united nations protect, respect and remedy framework'. United Nations, New York and Geneva.

United Nations (2015). Sustainable Development Goals, Retrieved June 19, 2018, from http://www.undp.org/content/undp/en/home/sustainable-development-goals.html.

United Nations (2018). International Mother Earth Day - 22 April, Retrieved February 7, 2019, from http://www.un.org/en/events/motherearthday/.

Urkidi, L. (2010). A glocal environmental movement against gold mining: Pascua-Lama in Chile. Ecological Economics 70(2), 219-227.

Urkidi, L. and Walter, M. (2011). Dimensions of environmental justice in anti-gold mining movements in Latin America. Geoforum 42(6), 683-695.

Vestas (2019). Climate Change, Retrieved March 4, 2019, from https://www.vestas.com/en/about/sustainability\#!

Walker, G. and Bulkeley, H. (2006). Geographies of environmental justice. Geoforum 37(5), 655-659.

Weinrub, A. and Giancatarino, A. (2015). Toward a Climate Justice Energy Platform: Democratizing our Energy Future, Retrieved November 18, 2018, from http://www.localcleanenergy.org/files/ClimateJusticeEnergyPlatform.pdf.

Zárate-Toledo, E., Patiño, R. and Fraga, J. (2019). Justice, social exclusion and indigenous opposition: A case study of wind energy development on the Isthmus of Tehuantepec, Mexico. Energy Research \& Social Science 54, 1-11.

Zografos, C. and Martínez-Alier, J. (2009). The politics of landscape value: A case study of wind farm conflict in rural Catalonia. Environment and Planning A: Economy and Space 41(7), 1726-1744. 
Table 1. Timeline of Major Events.

\begin{tabular}{|c|c|c|}
\hline Month & Critical Events & Theme \\
\hline $\begin{array}{l}\text { November } \\
1994\end{array}$ & $\begin{array}{l}\text { The Comisión Federal de Electricidad (CFE), which } \\
\text { is the state-owned electric utility of Mexico opens } \boldsymbol{L a} \\
\text { Venta 1: First mini wind farm opened ( } 7 \text { Vestas turbines) } \\
\text { to test wind energy potential on the Isthmus of } \\
\text { Tehuantepec. No consultation with local } \\
\text { communities according to ILO } 169 \text { Convention nor } \\
\text { Mexican laws took place. }\end{array}$ & $\begin{array}{l}\text { Assessment of wind } \\
\text { energy potential }\end{array}$ \\
\hline $\begin{array}{l}\text { February } \\
2006\end{array}$ & $\begin{array}{l}\text { Individual land proprietaries (indigenous people) } \\
\text { sign contracts to lease their lands to wind energy } \\
\text { investors. }\end{array}$ & $\begin{array}{l}\text { Payments and land } \\
\text { leasing }\end{array}$ \\
\hline March 2007 & $\begin{array}{l}\text { The CFE opens La Venta II: Second wind farm (98 } \\
\text { Iberdrola and Gamesa turbines). No consultation with } \\
\text { local communities according to ILO } 169 \text { Convention } \\
\text { nor Mexican laws took place. }\end{array}$ & $\begin{array}{l}\text { Development through } \\
\text { wind energy }\end{array}$ \\
\hline $\begin{array}{l}\text { February } \\
2007\end{array}$ & $\begin{array}{l}\text { Formal, organized indigenous people's protests against } \\
\text { wind energy farms. }\end{array}$ & $\begin{array}{l}\text { Enrollment in resistance } \\
\text { Protection of Mother } \\
\text { Earth }\end{array}$ \\
\hline $\begin{array}{l}\text { September } \\
2007\end{array}$ & $\begin{array}{l}\text { Establishment of the Assembly of Peoples of the Isthmus } \\
\text { in Defense of Land and Territory (APIIDTT). }\end{array}$ & $\begin{array}{l}\text { Organization of } \\
\text { indigenous people }\end{array}$ \\
\hline April 2011 & $\begin{array}{l}\text { Preneal sells the Mareña Renovables project to an } \\
\text { international consortium. }\end{array}$ & $\begin{array}{l}\text { Investment in green } \\
\text { business }\end{array}$ \\
\hline $\begin{array}{l}\text { June } \\
2011\end{array}$ & $\begin{array}{l}\text { IADB Report stating failures in consultation process for } \\
\text { the Mareña Renovables project. }\end{array}$ & $\begin{array}{l}\text { Rule of law } \\
\text { Ignoring laws and } \\
\text { conventions } \\
\text { (Procedural) }\end{array}$ \\
\hline $\begin{array}{l}\text { January } \\
2012\end{array}$ & $\begin{array}{l}\text { Indigenous people's protest against municipal authority } \\
\text { for receiving money from the wind consortium Mareña } \\
\text { Renovables. }\end{array}$ & $\begin{array}{l}\text { Corruption } \\
\text { Facilitating payments } \\
\text { (Procedural) }\end{array}$ \\
\hline $\begin{array}{l}\text { October } \\
2012\end{array}$ & $\begin{array}{l}\text { Mexican Federal Government announces the construction } \\
\text { of the wind farm La Venta III: "Mareña Renovables" to } \\
\text { contribute to fighting climate change and promote } \\
\text { regional development. }\end{array}$ & $\begin{array}{l}\text { Development through } \\
\text { wind energy } \\
\text { Technical solution to } \\
\text { climate change }\end{array}$ \\
\hline March 2012 & $\begin{array}{l}\text { Vestas receives a firm and unconditional order for } \\
132 \text { V90-3.0 MW wind turbines to build the Mareña } \\
\text { Renovables wind farm. }\end{array}$ & $\begin{array}{l}\text { Investment in wind } \\
\text { energy (Distributive) }\end{array}$ \\
\hline $\begin{array}{l}\text { September } \\
2012\end{array}$ & $\begin{array}{l}\text { Indigenous people report exploitations and fish death } \\
\text { at the Upper and Lower Lagoon. }\end{array}$ & $\begin{array}{l}\text { Environmental cost of } \\
\text { wind energy investment } \\
\text { (Distributive) }\end{array}$ \\
\hline
\end{tabular}


Table 1. Timeline of Major Events. (Continued).

\begin{tabular}{|l|l|l|}
\hline Month & Critical Events & Theme \\
\hline $\begin{array}{l}\text { October } \\
2012\end{array}$ & $\begin{array}{l}\text { Indigenous people's protests at the embassies of } \\
\text { Denmark and the Netherlands, as some businesses } \\
\text { involved in the Mareña Renovables project come } \\
\text { from those countries. }\end{array}$ & $\begin{array}{l}\text { Seeking justice at the } \\
\text { international level } \\
\text { (Recognition and } \\
\text { Procedural) }\end{array}$ \\
\hline $\begin{array}{l}\text { August } \\
2013\end{array}$ & $\begin{array}{l}\text { Assassination of Héctor Regalado Jiménez, a } \\
\text { member of the Asamblea Popular del Pueblo } \\
\text { Juchiteco (APPJ). }\end{array}$ & $\begin{array}{l}\text { Criminalization of } \\
\text { human rights defenders } \\
\text { Rule of law } \\
\text { Lack of peace } \\
\text { (Distributive) }\end{array}$ \\
\hline $\begin{array}{l}\text { December } \\
2013\end{array}$ & $\begin{array}{l}\text { Mexico's Energy Reform -Constitutional } \\
\text { amendments. The reform establishes the requirement } \\
\text { to consult indigenous people. }\end{array}$ & $\begin{array}{l}\text { Institutional transition } \\
\text { (Recognition and } \\
\text { Procedural) }\end{array}$ \\
\hline $\begin{array}{l}\text { October } \\
2014\end{array}$ & $\begin{array}{l}\text { The first public consultation at the Isthmus of Tehuantepec } \\
\text { in relation to the Mareña Renovables project begins. } \\
\text { Indigenous people and NGOs report manipulations in } \\
\text { the consultation process, which are denied by the } \\
\text { Mexican government and involved businesses. }\end{array}$ & $\begin{array}{l}\text { Rule of law } \\
\text { Conflicting visions of } \\
\text { environmental justice } \\
\text { (Procedural) }\end{array}$ \\
\hline $\begin{array}{l}\text { October } \\
2015\end{array}$ & $\begin{array}{l}\text { Cancelation of the Mareña Renovables project by a local } \\
\text { judge. }\end{array}$ & $\begin{array}{l}\text { Enactment of laws at } \\
\text { State level (Recognition } \\
\text { and Procedural) }\end{array}$ \\
\hline $\begin{array}{l}\text { February } \\
2015\end{array}$ & $\begin{array}{l}\text { Mareña Renovables project changes name to Eólicas de } \\
\text { Sur. }\end{array}$ & $\begin{array}{l}\text { Detachment } \\
\text { Unofficial } \\
\text { acknowledgement of } \\
\text { unfair process }\end{array}$ \\
\hline $\begin{array}{l}\text { June } \\
2015\end{array}$ & $\begin{array}{l}\text { End of the consultation process of the Eolicas del Sur } \\
\text { project. Business and Mexican Federal Government } \\
\text { declares a "successful" consultation process. }\end{array}$ & $\begin{array}{l}\text { Conflicting visions of } \\
\text { environmental justice } \\
\text { Division of indigenous } \\
\text { people communities: } \\
\text { Supporters of and } \\
\text { opponents to wind } \\
\text { farms. }\end{array}$ \\
\hline $\begin{array}{l}\text { Recognition of } \\
\text { Indigenous people's } \\
\text { rights. } \\
\text { Recognition of failures } \\
\text { in the consultation } \\
\text { procedural stage } \\
\text { (Recognition and } \\
\text { Procedural) }\end{array}$ \\
\hline
\end{tabular}


Table 1. Timeline of Major Events. (Continued).

\begin{tabular}{|c|c|c|}
\hline Month & Critical Events & Theme \\
\hline $\begin{array}{l}\text { January } \\
2018\end{array}$ & $\begin{array}{l}\text { Mexican Supreme Court recognizes the writ amparo } \\
\text { against the Eólica del Sur Project }\end{array}$ & $\begin{array}{l}\text { Recognition of } \\
\text { potentially unfair } \\
\text { consultation process. }\end{array}$ \\
\hline July 2018 & $\begin{array}{l}\text { In relation to the Eólica del Sur project, Mr. Rolando } \\
\text { Crispín López, a member of the communal assembly at } \\
\text { Alvaro Obregón, is assassinated. }\end{array}$ & $\begin{array}{l}\text { Criminalization of } \\
\text { human rights defenders } \\
\text { Rule of law } \\
\text { Lack of peace }\end{array}$ \\
\hline $\begin{array}{l}\text { December } \\
2018\end{array}$ & $\begin{array}{l}\text { Mexican supreme court denies the writ amparo against the } \\
\text { Eolica del Sur Project. }\end{array}$ & $\begin{array}{l}\text { Enactment of laws at } \\
\text { Federal level } \\
\text { (Recognition and } \\
\text { Procedural) }\end{array}$ \\
\hline $\begin{array}{l}\text { January } \\
2019\end{array}$ & $\begin{array}{l}\text { Communal Assemblies at the Isthmus of Tehuantepec } \\
\text { seek to take the case against the Eolica del Sur to the Inter- } \\
\text { American Court of Human Rights. }\end{array}$ & $\begin{array}{l}\text { Seeking environmental } \\
\text { justice internationally }\end{array}$ \\
\hline $\begin{array}{l}\text { February } \\
2019\end{array}$ & $\begin{array}{l}\text { Communal Assemblies at the Isthmus of Tehuantepec and } \\
\text { diverse NGOs continue to report human rights abuses in } \\
\text { relation to wind energy investments. }\end{array}$ & $\begin{array}{l}\text { Criminalization of } \\
\text { human rights defenders } \\
\text { Rule of law } \\
\text { Lack of peace } \\
\text { (Distributive) }\end{array}$ \\
\hline March 2019 & $\begin{array}{l}\text { Vestas declares that they do not have any documentation } \\
\text { indicating anything improper in their projects in Mexico. }\end{array}$ & Detachment \\
\hline May 2019 & $\begin{array}{l}\text { On the 28th of May } 2019 \text {, the Energia Eólica del Sur } \\
\text { wind farm, with } 132 \text { wind turbines installed on an } \\
\text { area of } 4,500 \text { hectares in the Isthmus of Tehuantepec, } \\
\text { Oaxaca, finally started operations with the capacity to } \\
\text { generate } 396 \text { megawatts. }\end{array}$ & Resilience \\
\hline
\end{tabular}


Table 2. Theoretical Abstraction.

\begin{tabular}{|c|c|}
\hline Theoretical Process & Summary of Theme \\
\hline Assessment of wind energy potential & \multirow{9}{*}{ Dysfunctional institutional context } \\
\hline New laws & \\
\hline $\begin{array}{l}\text { Constitutional change (Recognition and } \\
\text { Procedural) }\end{array}$ & \\
\hline $\begin{array}{l}\text { Development through wind energy } \\
\text { Technical solution to climate change }\end{array}$ & \\
\hline Corruption & \\
\hline Rule of Law & \\
\hline Facilitating payments (Procedural) & \\
\hline $\begin{array}{l}\text { Enactment of laws at State level (Recognition } \\
\text { and Procedural) }\end{array}$ & \\
\hline $\begin{array}{l}\text { Enactment of laws at Federal level } \\
\text { (Recognition and Procedural) }\end{array}$ & \\
\hline Payments for land leasing & \multirow{3}{*}{$\begin{array}{l}\text { Indigenous people's conflicting visions of } \\
\text { Mother Earth }\end{array}$} \\
\hline $\begin{array}{l}\text { Criminalization of human rights defenders } \\
\text { Lack of peace } \\
\text { (Distributional) }\end{array}$ & \\
\hline $\begin{array}{l}\text { Division of indigenous communities: } \\
\text { Supporters of and opponents to wind farms }\end{array}$ & \\
\hline Ignoring laws and conventions (Procedural) & \multirow{3}{*}{ Businesses' conflicting ethical behavior } \\
\hline $\begin{array}{l}\text { Detachment } \\
\text { Unofficial acknowledgement of unfair process }\end{array}$ & \\
\hline $\begin{array}{l}\text { Recognition of Indigenous people's rights } \\
\text { Recognition of failures in the consultation } \\
\text { procedural stage (Recognition and Procedural) }\end{array}$ & \\
\hline $\begin{array}{l}\text { Enrollment to resistance } \\
\text { Protection Mother Earth }\end{array}$ & \multirow{4}{*}{ Resilience in seeking environmental justice } \\
\hline Organization of indigenous people & \\
\hline $\begin{array}{l}\text { Seeking justice at international level (Recognition } \\
\text { and Procedural) }\end{array}$ & \\
\hline $\begin{array}{l}\text { Environmental cost of wind energy investment } \\
\text { (Distribution) }\end{array}$ & \\
\hline
\end{tabular}




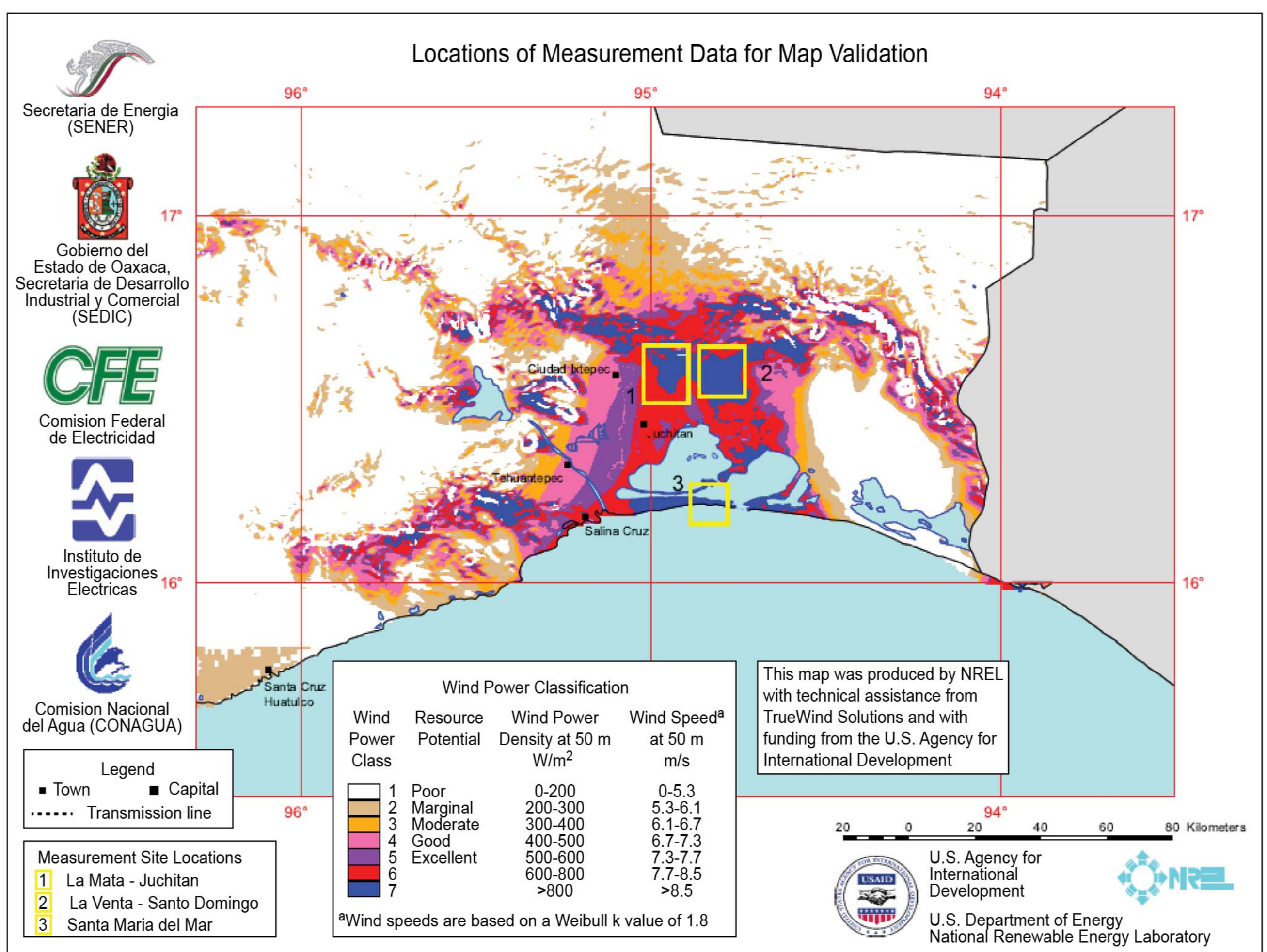

Elliott, D., Schwartz, M., Scott, G., Haymes, S., Heimiller, D., \& George, R. (2003).

*Wind Energy Resource Atlas of Oaxaca*. Golden, CO.; https://doi.org/10.2172/15004364; Figure taken from Page 45 


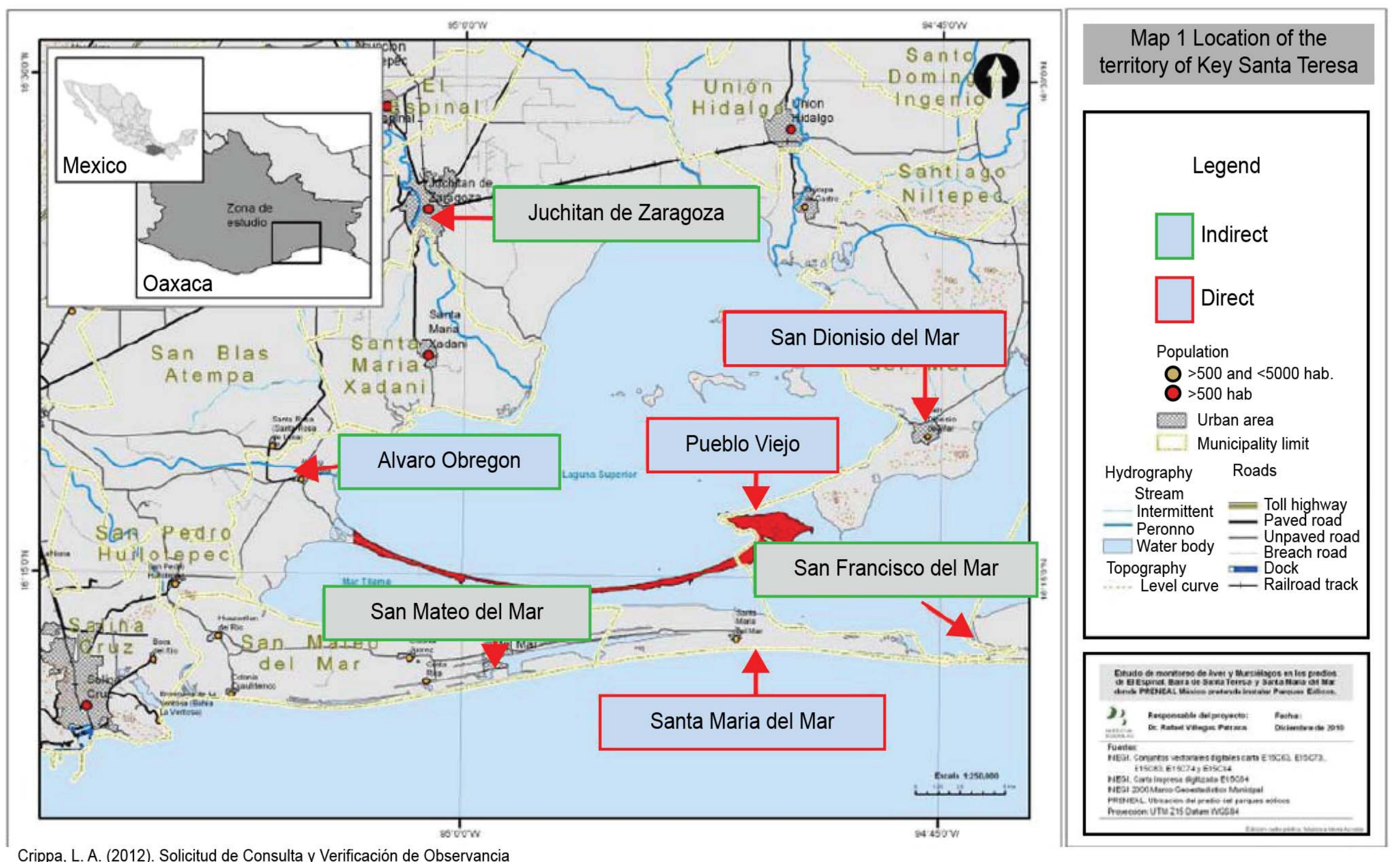

Crippa, L. A. (2012). Solicitud de Consulta y Verificación de Observancia

Proyecto Eólico Mareña Renovables ME-L1107. Washington. Retrieved March 25, 2013, from http://idbdocs.iadb.org/wsdocs/getdocument.aspx?docnum=37602983" 